\title{
The dual effects of Maillard reaction and enzymatic hydrolysis on the antioxidant activity of milk proteins
}

\author{
N. S. Oh, ${ }^{*}$ H. A. Lee, ${ }^{*}$ J. Y. Lee, ${ }^{*}$ J. Y. Joung, ${ }^{*}$ K. B. Lee, ${ }^{*}$ Y. Kim,† K. W. Lee,‡ and S. H. Kim ${ }^{1}$ \\ ${ }^{*}$ Research and Development Center, Seoul Dairy Cooperative, Ansan, Kyunggi 425-839, South Korea \\ †Department of Animal Science and Institute of Rare Earth for Biological Application, Chonbuk National University, Jeonju, 561-756, South Korea \\ ‡Division of Food Bioscience and Technology, College of Life Science and Biotechnology, Korea University, Seoul 136-701, South Korea
}

\section{ABSTRACT}

The objective of this study was to determine the enhanced effects on the biological characteristics and antioxidant activity of milk proteins by the combination of the Maillard reaction and enzymatic hydrolysis. Maillard reaction products were obtained from milk protein preparations, such as whey protein concentrates and sodium caseinate with lactose, by heating at $55^{\circ} \mathrm{C}$ for $7 \mathrm{~d}$ in sodium phosphate buffer ( $\mathrm{pH}$ 7.4). The Maillard reaction products, along with untreated milk proteins as controls, were hydrolyzed for 0 to $3 \mathrm{~h}$ with commercial proteases Alcalase, Neutrase, Protamex, and Flavorzyme (Novozymes, Bagsværd, Denmark). The antioxidant activity of hydrolyzed Maillard reaction products was determined by reaction with $2,2^{\prime}$-azinobis(3-ethylbenzothiazoline-6-sulfonic acid) diammonium salt, their 1,1-diphenyl-2-picrylhydrazyl radical scavenging activity, and the ability to reduce ferric ions. Further characteristics were evaluated by the $o$ phthaldialdehyde method and sodium dodecyl sulfatePAGE. The degree of hydrolysis gradually increased in a time-dependent manner, with the Alcalase-treated Maillard reaction products being the most highly hydrolyzed. Radical scavenging activities and reducing ability of hydrolyzed Maillard reaction products increased with increasing hydrolysis time. The combined products of enzymatic hydrolysis and Maillard reaction showed significantly greater antioxidant activity than did hydrolysates or Maillard reaction products alone. The hydrolyzed Maillard reaction products generated by Alcalase showed significantly higher antioxidant activity when compared with the other protease products and the antioxidant activity was higher for the whey protein concentrate groups than for the sodium caseinate groups. These findings indicate that Maillard reaction products, coupled with enzymatic hydrolysis, could act as potential antioxidants in the pharmaceutical, food, and dairy industries.

Received January 24, 2013.

Accepted April 22, 2013.

${ }^{1}$ Corresponding author: saehkim@korea.ac.kr
Key words: antioxidant activity, enzymatic hydrolysis, Maillard reaction, milk protein

\section{INTRODUCTION}

Milk protein is known to contain valuable components and biologically active substances (Chevalier et al., 2001), and has been widely used as a functional ingredient in food applications. Milk proteins can be classified by 2 major groups: casein ( $80 \%$ of milk protein) and whey protein (20\% of milk protein; Fox and McSweeney, 2003). Enzymatic hydrolysis of milk proteins can influence their functional properties and improve their physical and chemical characteristics (Bertrand-Harb et al., 2002). Several biological peptides have been studied in milk protein hydrolysates, including ACE-inhibitory peptides (FitzGerald and Meisel, 2000), opioid peptides (Shah, 2000), antimicrobial peptides (Haque and Chand, 2008), antioxidant peptides (Pihlanto, 2006), and immune-modulatory peptides (Gauthier et al., 2006).

The Maillard reaction, also termed nonenzymatic browning, is a complex reaction that occurs between carbonyl and amine groups during food processing and storage. It produces a large number of Maillard reaction products (MRP), which play an important role in determining food characteristics including aroma, color, flavor, and texture (Fayle and Gerrard, 2002). At an early stage of the reaction, proteins containing free amino groups react with carbonyl groups of sugars to form reversible Schiff bases, which give rise to stable Amadori compounds through rearrangement. In the advanced stage of the reaction, Amadori compounds lead to the formation of colored and fluorescent substances (Jing and Kitts, 2002). Fluorescence and browning development in the Maillard reaction are generally used as indicators of the reaction rate and formation of MRP (Yeboah et al., 1999).

Several studies have been conducted on the effects of Maillard reaction with milk proteins and sugars. Maillard reaction products have shown antioxidant activity in both chemical model and food systems. Heated casein-glucose mixtures decreased rates of lipid peroxi- 
dation in an emulsified linoleic acid model. In addition, caseinate-sugar-derived MRP exhibited antioxidant activity against Fenton reactant-induced hydroxyl free radicals, but not against hydrophobic radicals ( $\mathrm{Gu}$ et al., 2009). Likewise, it was introduced that the products of Maillard-reacted casein and glucose or lactose had a greater antioxidant activity than did intact casein (McGookin and Augustin, 1991). Furthermore, the Maillard reaction improved the heat stability, emulsifying properties, and antioxidant activity of whey protein (Chevalier et al., 2001). Based on these results, we propose that physiologic and biologic functions of milk protein could be improved by the Maillard reaction. The aim of the present study was to determine the effect of the Maillard reaction on the characteristics and antioxidant activity of milk protein hydrolysates. Casein and whey protein concentrate hydrolysates were tested for their characteristics, radical scavenging activities, and reducing ability.

\section{MATERIALS AND METHODS}

\section{Chemicals}

The chemicals, including o-phthaldialdehyde (OPA), 2,2'-Azino-bis(3-ethylbenzothiazoline-6-sulfonic acid) diammonium salt (ABTS), potassium persulfate, 2,4,6-tripyridyl-s-triazine (TPTZ), 1,1-diphenyl2-picrylhydrazyl (DPPH), L-ascorbic acid, and iron (III) chloride hexahydrate, used in this study were purchased from Sigma Chemical Co. (St. Louis, MO). Whey protein concentrates (WPC; $4.6 \pm 0.2 \%$ of moisture, $82.0 \pm 1.0 \%$ of total protein, $5.5 \pm 1.0 \%$ of fat, $3.0 \pm 0.5 \%$ ash, and $7.2-9.7 \%$ of lactose) and sodium caseinate (SC; minimum $90.0 \%$ of total protein and maximum $0.2 \%$ of lactose) were obtained from Davisco Foods International Inc. (Le Sueur, MN) and Kerrygold (Dublin, Ireland), respectively. Commercial enzymes, Protamex (EC 3.4.21.62 and 3.4.24.28), Neutrase, Alcalase (EC 3.4.21.62), and Flavorzyme (EC 3.4.11.1), were obtained from Novozymes (Bagsværd, Denmark). Lactose monohydrate was purchased from Junsei Chemical Co. (Tokyo, Japan), tryptone from Oxoid (Basingstoke, UK), and iron (II) sulfate heptahydrate from Showa Chemicals (Osaka, Japan). All chemicals used were of analytical grade.

\section{Preparation of Milk Protein MRP}

The WPC or SC and lactose were dissolved in 0.1 $M$ sodium phosphate buffer ( $\mathrm{pH} 7.4$ ) as a $1: 5$ weight ratio of protein $(10 \mathrm{mg})$ and sugar $(50 \mathrm{mg})$. (In the preliminary experiment, we found that the 1:5 ratio is the optimum combination compared with other conditions, such as 1:1 or 1:1 ratios.) The reaction was allowed to proceed at $55^{\circ} \mathrm{C}$ at $60 \mathrm{rpm}$ in a water bath for $7 \mathrm{~d}$. The $\mathrm{pH}$ value was not controlled during the reaction. Reaction mixtures were extensively dialyzed against 0.1 $M$ sodium phosphate buffer ( $\mathrm{pH}$ 7.4) 3 times within 24 $\mathrm{h}$ and were lyophilized.

\section{Hydrolysis of MRP from WPC-Lactose and SC-Lactose}

The MRP from WPC-lactose and SC-lactose were hydrolyzed using 4 different commercial enzymes: Protamex [1.5 arbitrary units (AU)/g], Neutrase $(0.8 \mathrm{AU} / \mathrm{g})$, Alcalase (2.4 AU/g) and Flavorzyme (500 LAPU/g). Hydrolysis parameters were an enzyme-to-substrate ratio of 1:100 (wt/vol); a temperature of $50^{\circ} \mathrm{C}$ for Neutrase, Alcalase, and Flavorzyme; and a temperature of $40^{\circ} \mathrm{C}$ for Protamex. Samples were withdrawn after 1, 2 , and $3 \mathrm{~h}$ of treatment from each proteolytic mixture and were immediately heated at $85^{\circ} \mathrm{C}$ for 5 min to inactivate the enzyme activity. Hydrolyzed MRP were UF by centrifugation at $15^{\circ} \mathrm{C}(7,000 \times g, 30 \mathrm{~min})$ using a 10 kDa Vivaspin 20 (Sartorius, Goettingen, Germany).

\section{Measurement of Furosine and Fluorescence}

Samples were hydrolyzed with $8 \mathrm{M} \mathrm{HCl}$ for $24 \mathrm{~h}$ at $110^{\circ} \mathrm{C}$ in dry oven. Hydrolysate obtained from acid hydrolysis was filtered using a Millipore (Millipore, Milford, MA) system with $0.45-\mu \mathrm{m}$ membrane filters (13 $\mathrm{mm}$ ). Five hundred microliters of hydrolysate was added to a Sep-pak $\mathrm{C}_{18}$ cartridge (Millipore) and activated with methanol $(5 \mathrm{~mL})$ and deionized water $(10 \mathrm{~mL})$. The furosine was then eluted with $3 \mathrm{~mL}$ of $3 \mathrm{M} \mathrm{HCl}$ and evaporated under nitrogen gas. The dried sample was dissolved in a mixture $(3 \mathrm{~mL})$ of water, acetonitrile, and formic acid (95:5:0.2; vol ratio) before HPLC analysis. An HPLC system (Alliance, Waters, USA) equipped with photo-diode array detector monitored at $280 \mathrm{~nm}$ for the analysis of furosine was analyzed onto a Capcell Pak $\mathrm{C}_{18}$ UG column $(4.6 \times 250 \mathrm{~mm})$ and kept at $30^{\circ} \mathrm{C}$. The analytical conditions were a flow rate of $1.0 \mathrm{~mL} / \mathrm{min}$ and an eluent solution of $5 \mathrm{mM}$ sodium heptane sulfonate with $20 \%$ (vol/vol) acetonitrile and $0.2 \%$ ( vol $/ \mathrm{vol}$ ) formic acid. The fluorescence intensity for MRP was measured at an excitation of $370 \mathrm{~nm}$ and an emission of $440 \mathrm{~nm}$ with a Synergy H1 plate reader (Bio-Tek Instruments Inc., Winooski, VT).

\section{Degree of Hydrolysis}

The degree of hydrolysis ( $\mathbf{D H})$ was determined with the OPA method described by Nielsen et al. (2006). The peptide concentration was calculated from a standard 
Table 1. Furosine content in Maillard-reacted whey protein concentrates (WPC) and sodium caseinate (SC) with lactose during heating at $55^{\circ} \mathrm{C}$ for $7 \mathrm{~d}^{1}$

\begin{tabular}{lccccccc}
\hline & \multicolumn{5}{c}{ Heating time $(\mathrm{d})$} \\
\cline { 2 - 7 } \begin{tabular}{l} 
Sample \\
\cline { 2 - 4 }$/ \mathrm{mL})$
\end{tabular} & 0 & 1 & 2 & 3 & 5 & 6 \\
\hline WPC & $16.8 \pm 0.1$ & $8.8 \pm 0.8$ & $4.71 \pm 0.07$ & $3.68 \pm 0.04$ & $2.3 \pm 0.3$ & $1.6 \pm 0.2$ & $1.19 \pm 0.02$ \\
WPC-lactose & $16.8 \pm 0.1$ & $13.2 \pm 0.2$ & $9.4 \pm 0.1$ & $9.65 \pm 0.01$ & $9.5 \pm 0.1$ & $9.6 \pm 0.3$ & $8.8 \pm 0.9$ \\
SC & $\mathrm{ND}^{2}$ & $\mathrm{ND}$ & $\mathrm{ND}$ & $\mathrm{ND}$ & $\mathrm{ND}$ & $\mathrm{ND}$ & $\mathrm{ND}$ \\
SC-lactose & $\mathrm{ND}$ & $2.7 \pm 0.4$ & $5.00 \pm 0.07$ & $5.7 \pm 0.5$ & $6.9 \pm 0.2$ & $7.1 \pm 0.2$ & $7.2 \pm 0.2$ \\
\hline
\end{tabular}

${ }^{1}$ Values are expressed as the mean $\pm \mathrm{SD}(\mathrm{n}=3)$.

${ }^{2} \mathrm{ND}=$ not detected.

curve prepared using tryptone $(0.25-1.5 \mathrm{mg} / \mathrm{mL})$. The samples, standard or blank (deionized water) groups $(30 \mu \mathrm{L})$, were mixed with $1 \mathrm{~mL}$ of OPA reagent and then allowed to react at room temperature for $2 \mathrm{~min}$. The absorbance was measured with a Synergy H1 plate reader (Bio-Tek Instruments Inc.) at $340 \mathrm{~nm}$.

\section{SDS-PAGE}

Hydrolyzed MRP were analyzed by SDS-PAGE by the procedure of Laemmli, as described previously (Laemmli, 1970). Protein concentration was quantified using a Synergy H1 plate reader (Bio-Tek Instruments Inc.) with the Take3 microdrop addition. Each sample was redissolved in SDS-PAGE sample buffer [62.5 $\mathrm{mM}$ Tris-HCl, $\mathrm{pH} 6.8 ; 2 \%$ (wt/vol) SDS; $25 \%$ (vol/vol) glycerol; $5 \%$ (vol/vol) 2-mercaptoethanol; $0.01 \%$ (wt/ vol) bromophenol blue], and then denatured at $100^{\circ} \mathrm{C}$ for 5 min. Twenty micrograms of protein samples were loaded on 10\% Ready Gel Tris-HCl Gel (Bio-Rad) and

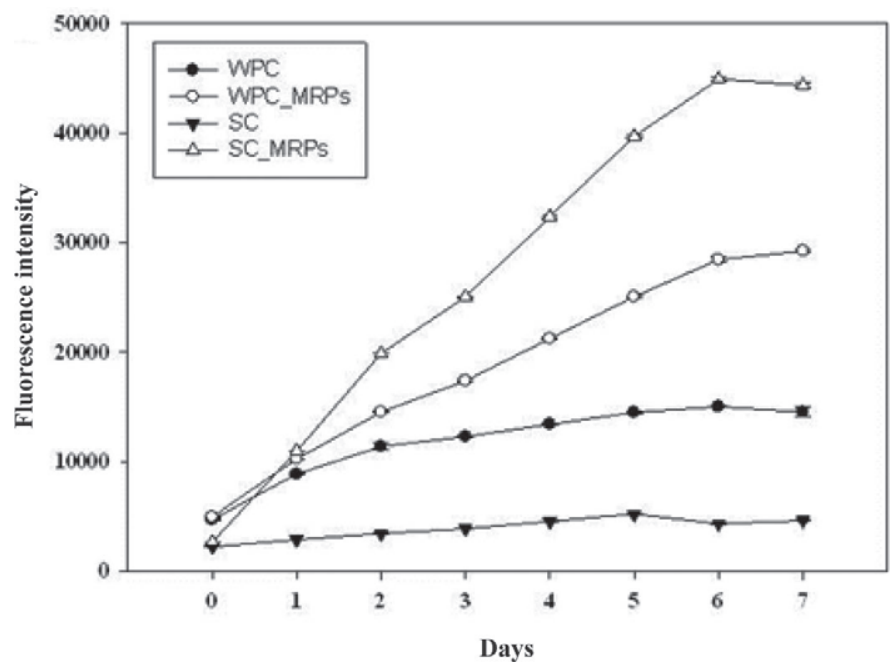

Figure 1. Changes of fluorescence in Maillard-reacted whey protein concentrates (WPC) and sodium caseinate (SC) with lactose during heating at $55^{\circ} \mathrm{C}$ for $7 \mathrm{~d}$. Values are expressed as the mean $\pm \mathrm{SD}(\mathrm{n}$ $=3) . \mathrm{MRP}=$ Maillard reaction products. stained with Coomassie Brilliant Blue R-250 Staining Solution (Bio-Rad).

\section{Antioxidant Activity}

Determination of DPPH Radical Scavenging Activity. The radical scavenging properties of MRP hydrolysates followed the slightly modified method described by Blois (1958). An aliquot of sample (100 $\mu \mathrm{L}$ ) was added to $100 \mu \mathrm{L}$ of $200 \mu M \mathrm{DPPH}$ in ethanol. The solution was then mixed vigorously and allowed to stand at $37^{\circ} \mathrm{C}$ in the dark for $30 \mathrm{~min}$. The absorbance of the solution was measured spectrophotometrically at $517 \mathrm{~nm}$ (OD = optical density). For comparison, the assay was conducted in the same manner but ascorbic acid was added instead of sample solution. The percentage of DPPH radical scavenging activity was calculated from the equation

$$
\mathrm{DPPH}=\frac{\mathrm{OD}_{\text {control }}-\mathrm{OD}_{\text {sample }}}{\mathrm{OD}_{\text {control }}} \times 100 .
$$

Determination of ABTS Radical Scavenging Activity. The ABTS radical scavenging activity of MRP hydrolysates was evaluated according to the method described by Re et al. (1999). The ABTS solution prepared from $7 \mathrm{~m} M$ ABTS and $2.45 \mathrm{~m} M$ potassium persulfate previously was diluted with deionized water to an absorbance of 1.4 at $734 \mathrm{~nm}$, approximately. Twenty microliters of the sample were added to $180 \mu \mathrm{L}$ of diluted ABTS solution and kept in the dark for 6 min at room temperature $\left(25^{\circ} \mathrm{C}\right)$ after shaking. Then the absorbance of the mixtures was measured at 734 nm. Ascorbic acid was used as a positive control. The percentage of ABTS radical scavenging activity was calculated by

$$
\mathrm{ABTS}=\frac{\mathrm{OD}_{\text {control }}-\mathrm{OD}_{\text {sample }}}{\mathrm{OD}_{\text {control }}} \times 100 .
$$

Finally, the results were indicated as $\mathrm{IC}_{50}$ values, the concentration of sample required to scavenge $50 \%$ of ABTS radical. 

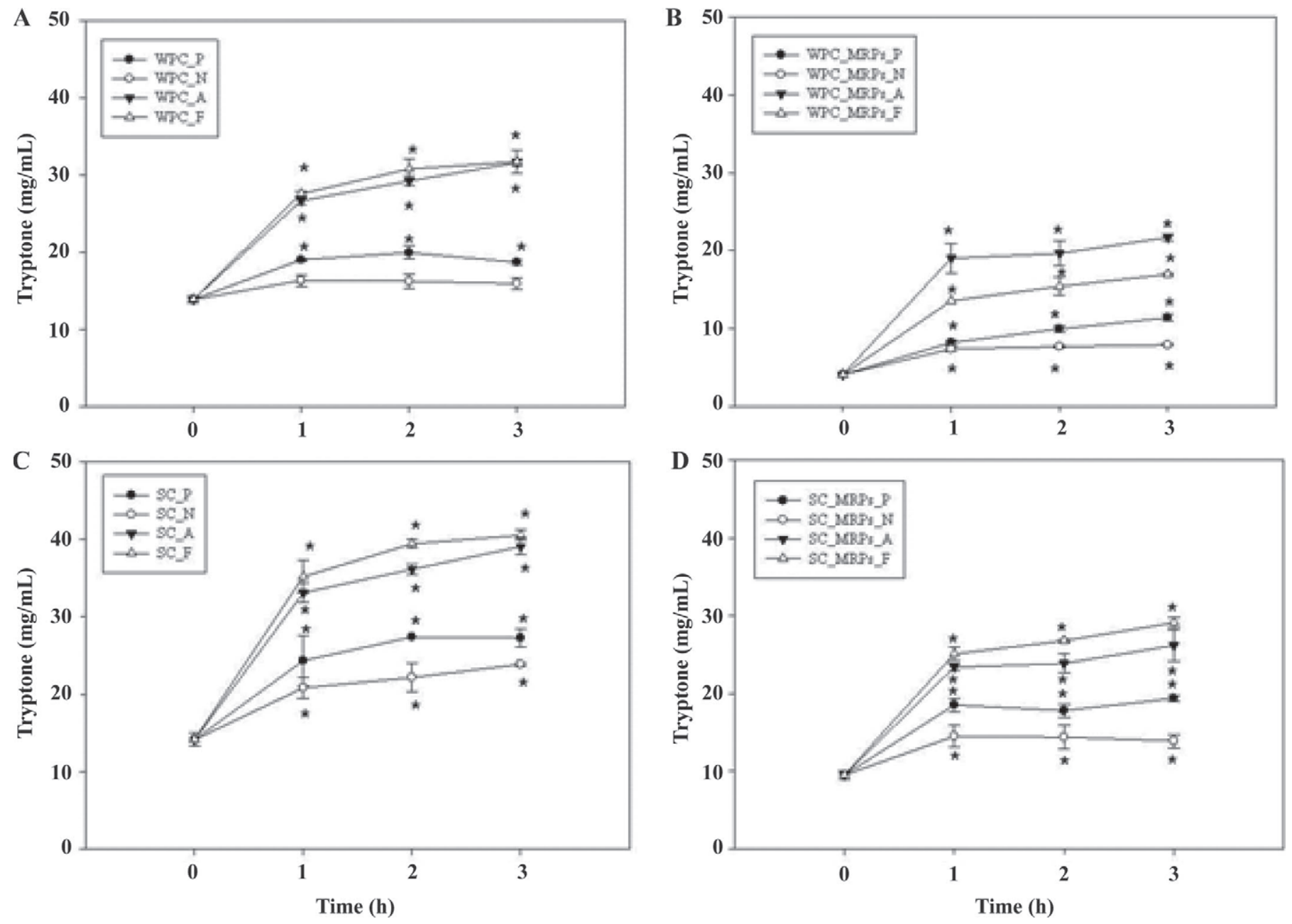

Figure 2. Degree of hydrolysis of (A) whey protein concentrates (WPC), (B) Maillard-reacted WPC, (C) sodium caseinate (SC), and (D) Maillard-reacted SC by different enzymes (all from Novozymes, Bagsværd, Denmark). MRP = Maillard reaction products; $\mathrm{P}=\mathrm{Protamex}$; $\mathrm{N}=$ Neutrase; $\mathrm{A}=$ Alcalase; $\mathrm{F}=$ Flavorzyme. Values are expressed as the mean $\pm \mathrm{SD}(\mathrm{n}=3) .{ }^{*} P<0.05$ compared with the control group.

Ferric-Reducing Antioxidant Power Assay. The reducing ability of MRP hydrolysate was measured using the ferric-reducing antioxidant power (FRAP) assay (Benzie and Strain, 1996). The FRAP reagent was prepared with $0.3 \mathrm{M}$ sodium acetate buffer ( $\mathrm{pH} 3.6$ ), 10 $\mathrm{m} M$ TPTZ in $40 \mathrm{~m} M \mathrm{HCl}$, and $20 \mathrm{~m} M \mathrm{FeCl}_{3} \cdot 6 \mathrm{H}_{2} \mathrm{O}$ in the ratio of 10:1:1 (vol ratio), respectively. Six microliters of hydrolyzed MRP solution was mixed with $180 \mu \mathrm{L}$ of each freshly prepared FRAP reagent and incubated at $37^{\circ} \mathrm{C}$ for $30 \mathrm{~min}$. Then the absorbance of mixtures was read at $562 \mathrm{~nm}$. Ascorbic acid was used as a positive control. The FRAP values were calculated based on a $\mathrm{Fe}_{2} \mathrm{SO}_{4}$ standard curve.

\section{Statistical Analysis}

All data were expressed as means \pm SD. Statistical significance for the differences between the groups was assessed using Duncan's multiple range tests. SAS software version 9.2 (SAS Institute, Cary, NC) was used to perform all statistical tests. Values of $P<0.05$ were considered to indicate a significant difference.

\section{RESULTS AND DISCUSSION}

\section{Measurement of Maillard Reaction in WPC and SC Milk Proteins}

The determination of furosine was used to evaluate the early stages of the Maillard reaction (GuerraHernández et al., 1999). Furosine content ranged between $1.19 \pm 0.02$ and $16.76 \pm 0.13 \mu \mathrm{g} / \mathrm{mL}$ (Table 1 ). During the heat treatment, furosine content decreased in WPC and Maillard-reacted WPC, whereas it increased in Maillard-reacted SC. Before heat treatment, furosine was detected in WPC at $16.76 \pm 0.13 \mu \mathrm{g} /$ 

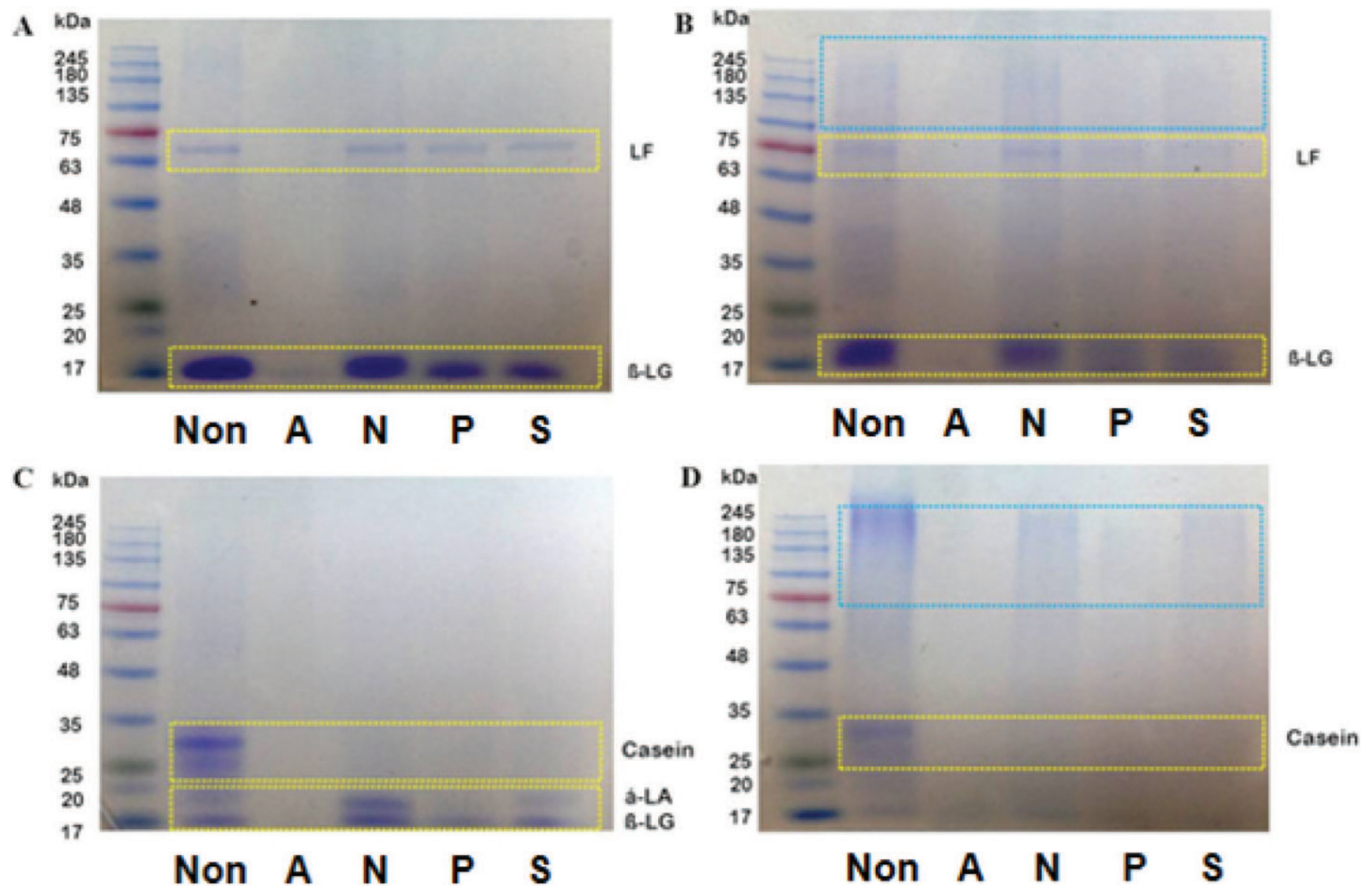

Figure 3. The SDS-PAGE patterns of 3 h enzymatic hydrolysates of (A) whey protein concentrates (WPC), (B) Maillard-reacted WPC, (C) sodium caseinate (SC), and (D) Maillard-reacted SC. Non = nontreated sample; A = Alcalase-treated sample; $\mathrm{N}=\mathrm{Neutrase-treated} \mathrm{sample;} \mathrm{P}$ = Protamex-treatment sample; and $\mathrm{S}=$ Flavorzyme-treated sample (all enzymes from Novozymes, Bagsværd, Denmark). The top box in (B) and (D) represents the fraction for MRP = Maillard reaction products, and the other dotted boxes represent the fractions of other components $(\mathrm{LF}=$ lactoferrin $)$. Color version available in the online PDF.

$\mathrm{mL}$, but it was not detected in SC. This suggested that furosine had already been synthesized by the heat treatment in the processing of WPC containing lactose. Moreover, during the heating, the furosine content decreased less in the Maillard-reacted WPC than in the WPC heated without lactose, as a result of the additional furosine synthesized in the early stage of the Maillard reaction in the presence of added lactose, compared with intact WPC. The results from a previous study also reported the effects of heat treatment on the furosine content of model systems heated at $120^{\circ} \mathrm{C}$ (Angel Rufian-Henares et al., 2002). According to this study, the furosine content in the whey protein and whey protein-dextrinomaltose model systems decreased during the heating and increased in the casein-lactose and casein-dextrinomaltose systems, in agreement with our results.

Development of fluorescent compounds has been reported to occur during the heat-induced Maillard reaction (Jing and Kitts, 2002). The fluorescence intensity of Maillard-reacted milk protein is shown in Figure 1. The fluorescence intensity of Maillard-reacted WPC and SC increased gradually during the 7-d heating period, by 5.89- and 16.65-fold, respectively, whereas the fluorescence intensity of non-Maillard-reacted WPC and SC increased only 3.08- and 2.09-fold, respectively. The rate of increase in fluorescence intensity of Maillard-reacted WPC and SC decreased after $6 \mathrm{~d}$. After $7 \mathrm{~d}$, compared with non-Maillard-reacted groups, the fluorescence of Maillard-reacted WPC and SC increased 2.01- and 9.56-fold, respectively.

Previous studies indicated that fluorescence, considered to reflect possible precursors of brown pigments, characteristically develops during the intermediate stages of the Maillard reaction (Nursten, 2005). Other studies have also reported that glucose- and fructosecasein models showed a similar fluorescence pattern of gradual increases in fluorescence with increasing heating time (Jing and Kitts, 2002). Moreover, several studies have shown that the source of the sugar component 

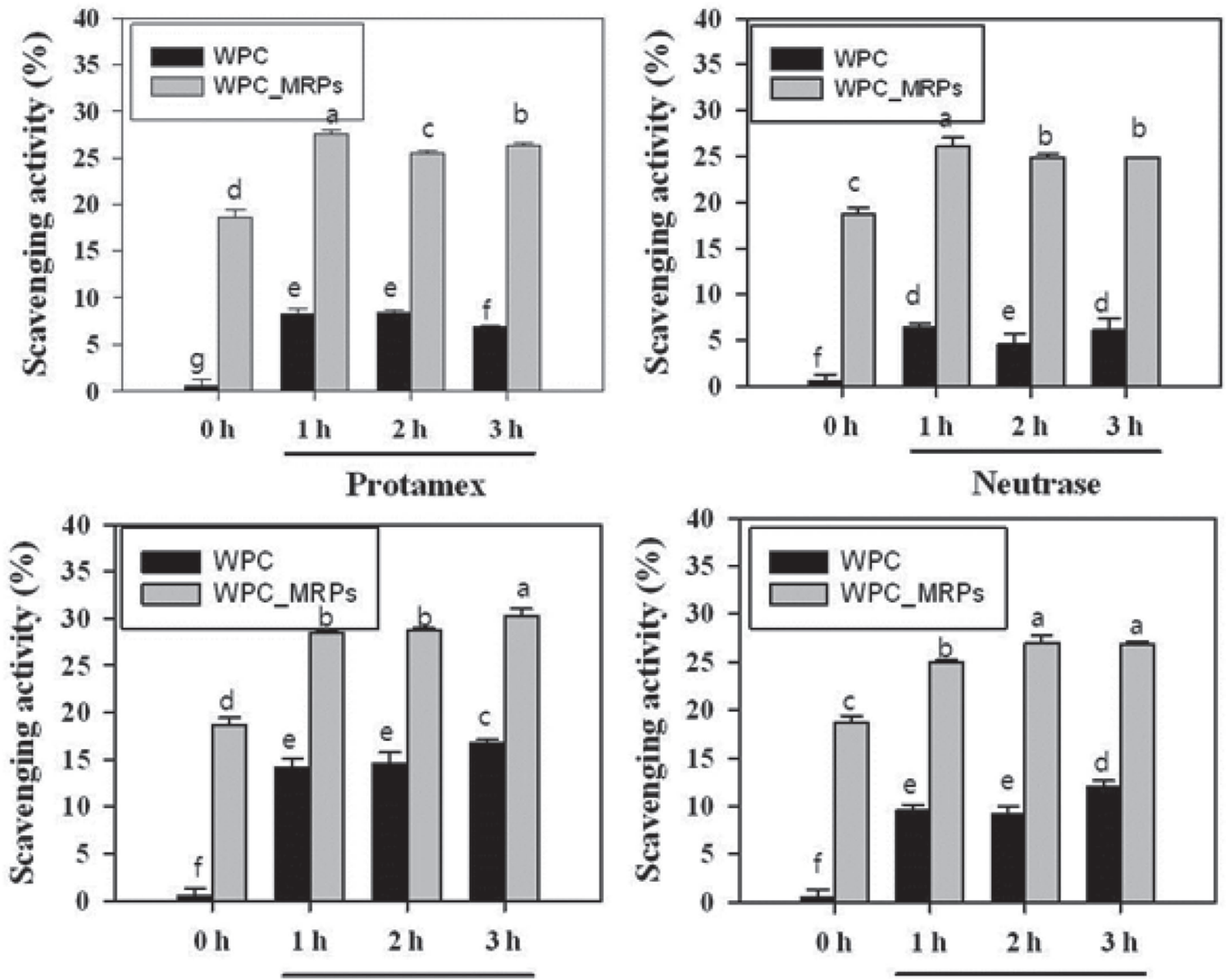

Alcalase

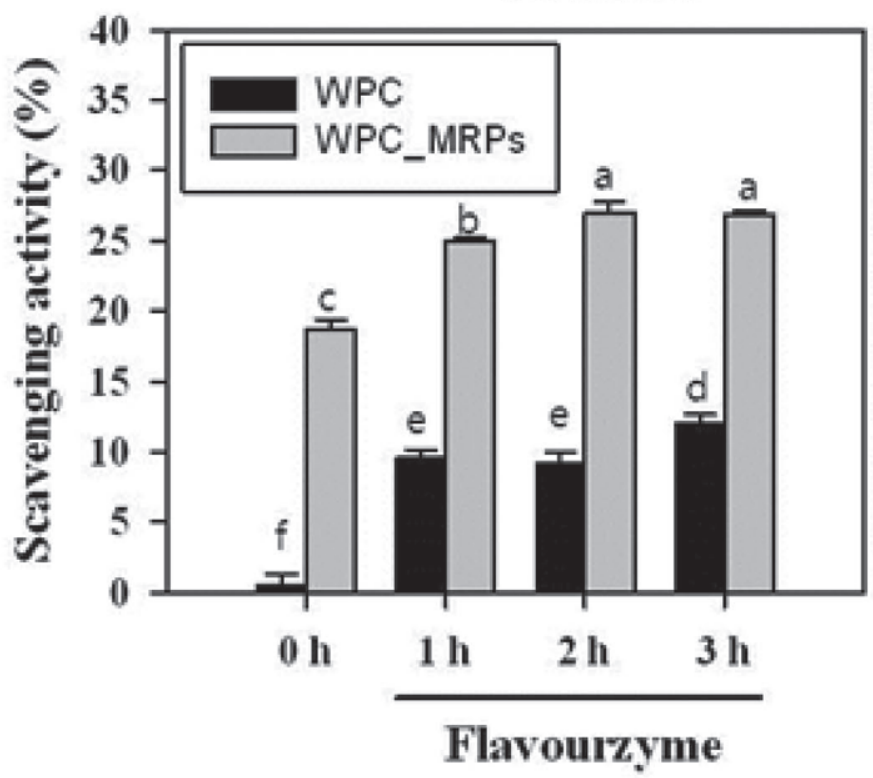

Figure 4. The 1,1-diphenyl-2-picrylhydrazyl radical-scavenging activity of whey protein concentrates (WPC) hydrolysates and Maillardreacted WPC. Values are expressed as the mean $\pm \mathrm{SD}(\mathrm{n}=3)$. Data followed by a different lowercase letter $(\mathrm{a}-\mathrm{f})$ were significantly different $(P$ $<0.05) . \mathrm{MRP}=$ Maillard reaction products. All enzymes were from Novozymes (Bagsværd, Denmark).

of the MRP influenced the fluorescence and browning development patterns in the sugar-casein model (Hollnagel and Kroh, 1998; Yeboah et al., 1999). In the present study, SC was more reactive than WPC, whereas similar fluorescence patterns were found for the WPCand SC-lactose models. This indicated that changes in fluorescence in the Maillard reaction could be affected by the source of protein as well as the type of sugar.

\section{Degree of Hydrolysis with Commercial Proteases}

Degree of hydrolysis was determined by the OPA method and the peptide concentration was expressed against a tryptone standard. As shown in Figure 2, the values of $\mathrm{DH}$ were gradually increased by hydrolysis time and were affected by the type of enzyme used (i.e., Alcalase, Neutrase, Protamex, Flavorzyme). The tryptone content of WPC and SC ranged from 13.36 to $31.71 \mathrm{mg} / \mathrm{mL}$, with and without the Maillard reaction. In all groups, proteins were mostly hydrolyzed within an hour. Compared with non-Maillard-reacted groups, the tryptone contents were lower in the hydrolyzed MRP groups, possibly because the cross-linked MRP were not susceptible to hydrolysis by the enzymes. After the $3 \mathrm{~h}$ of hydrolysis, the tryptone content was generally higher from SC than from WPC. Among different 

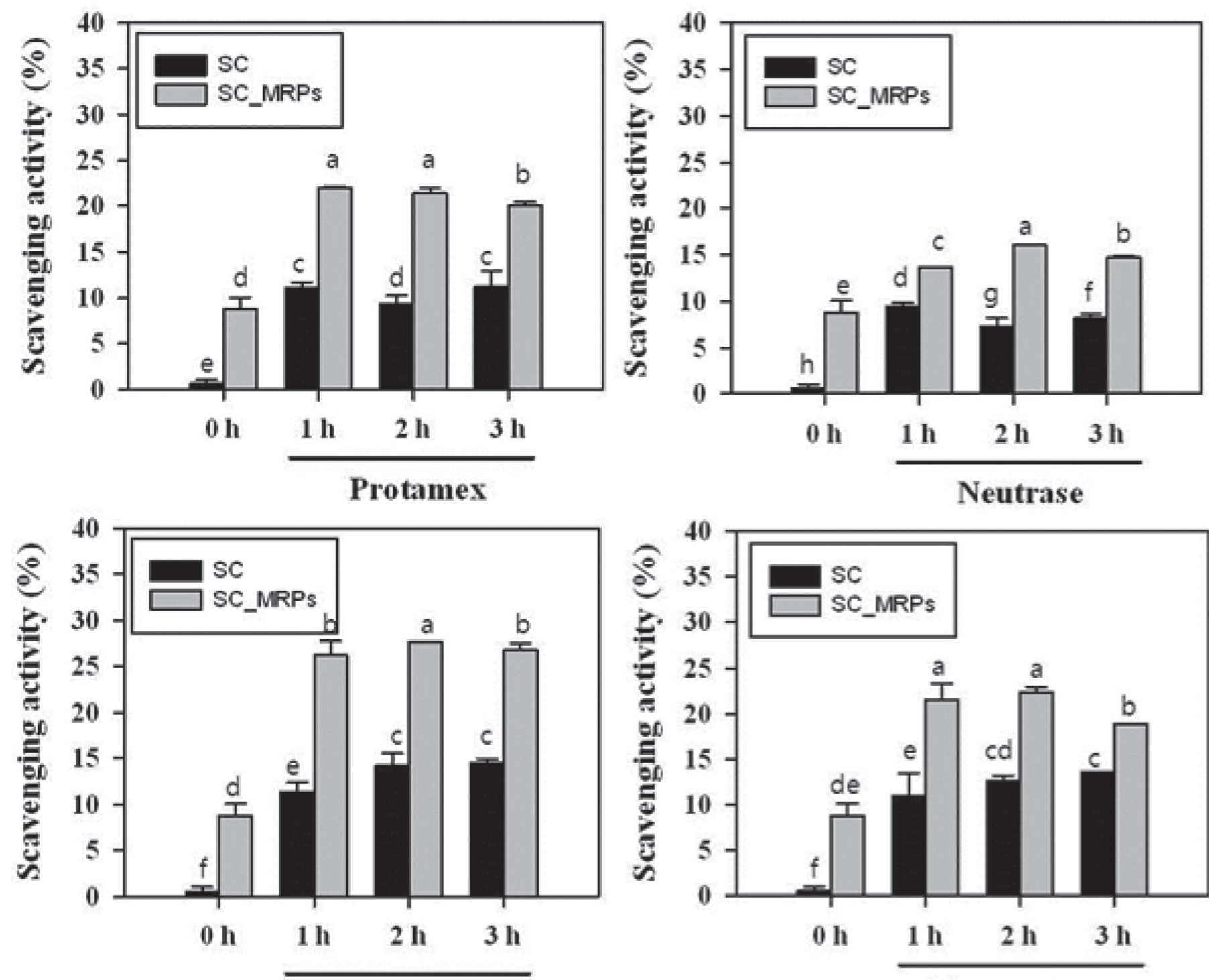

Alcalase

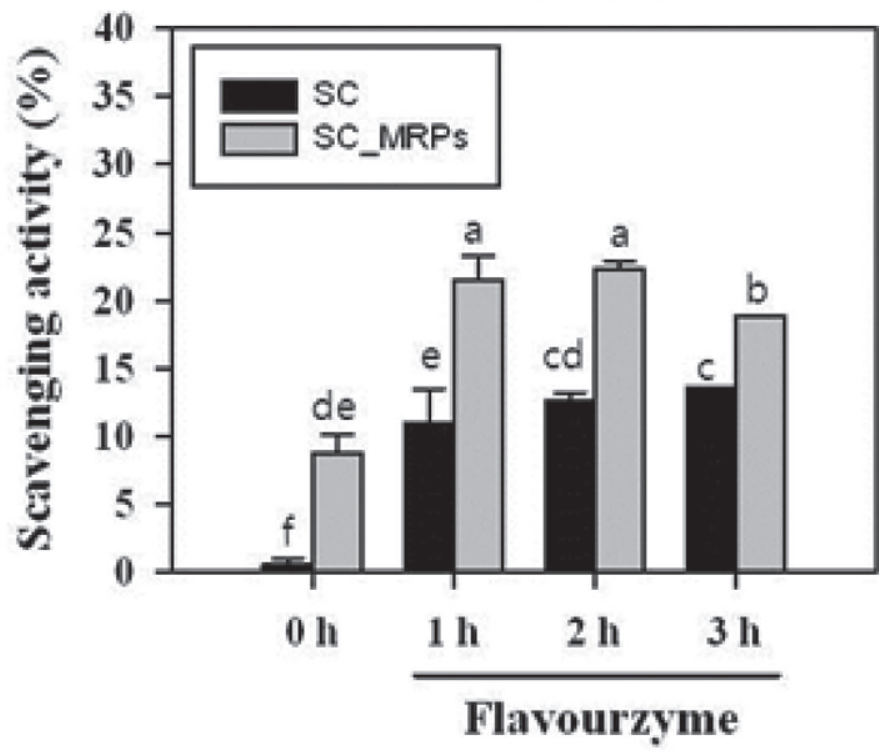

Figure 5. The 1,1-diphenyl-2-picrylhydrazyl radical-scavenging activity of sodium caseinate (SC) hydrolysates and Maillard-reacted SC. All enzymes were from Novozymes (Bagsværd, Denmark). Values are expressed as the mean $\pm \mathrm{SD}(\mathrm{n}=3)$. Data followed by a different lowercase letter $(\mathrm{a}-\mathrm{h})$ were significantly different $(P<0.05) . \mathrm{MRP}=$ Maillard reaction products.

enzyme treatments, the Flavorzyme-treated hydrolysates showed significantly higher $\mathrm{DH}$ values than did the other different enzyme treatments. The patterns of $\mathrm{DH}$ values differed by enzyme treatment due to the different nature of the catalytic sites of endopeptidases and exopeptidases (Reed, 1975). Flavorzyme is a crude enzyme with both endo- and exopeptidases activities, which most likely caused higher tryptone content compared with the other enzyme-treatments.

\section{Protein Profiles of Hydrolysates by SDS-PAGE}

The protein profiles of the hydrolysates were determined by SDS-PAGE (Figure 3). The WPC showed bands of lactoferrin and $\beta-\mathrm{LG}$, whereas bands of higher molecular weight, which were estimated as the bands of MRP, were found in electrophoretograms of Maillardreacted WPC. The electrophoresis results indicated that the molecular weights of the MRP ranged from 75 to $245 \mathrm{kDa}$ (Figure 3). Neither of these bands appeared in the WPC or Maillard-reacted WPC hydrolysates following Alcalase treatment for $3 \mathrm{~h}$, which suggested that lactoferrin, $\alpha$-LA, and $\beta$-LG were completely hydrolyzed as MRP were formed. Conversely, SC was almost completely hydrolyzed with all 4 enzyme treatments, and especially with Alcalase, where the highest degree of hydrolysis was observed. Sodium caseinate 


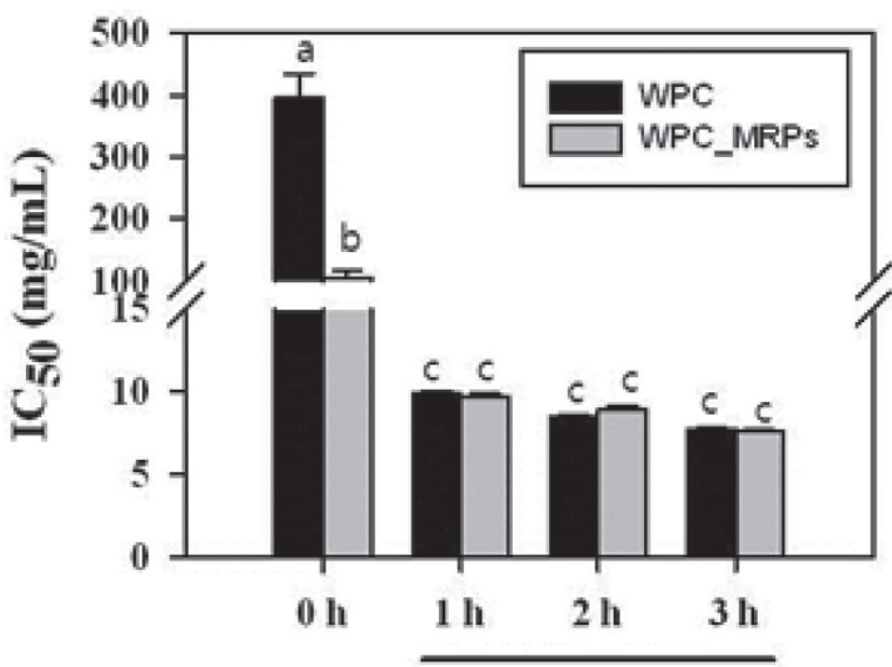

Protamex

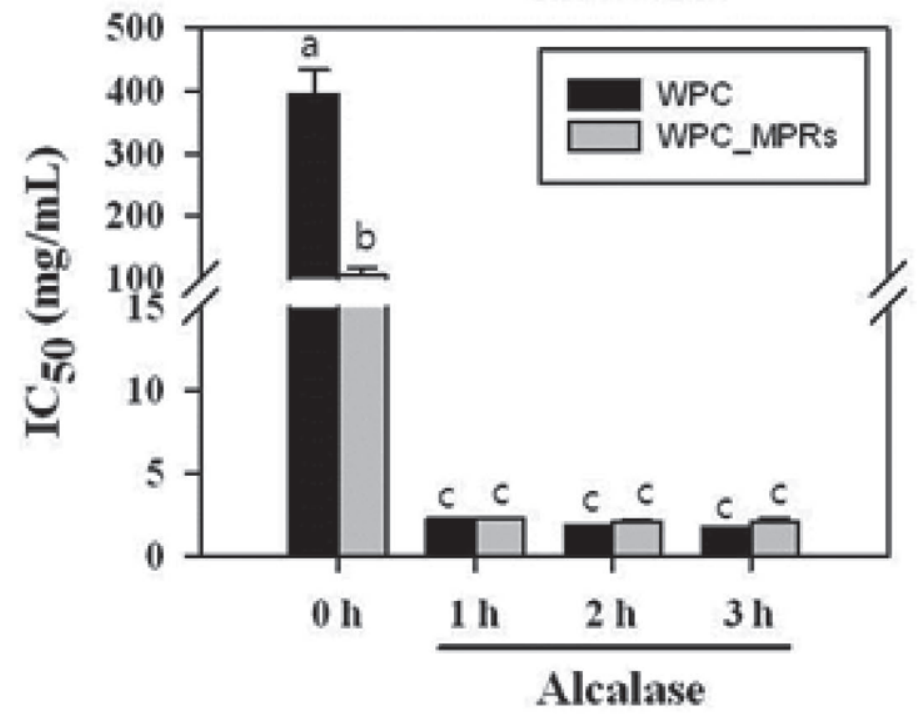

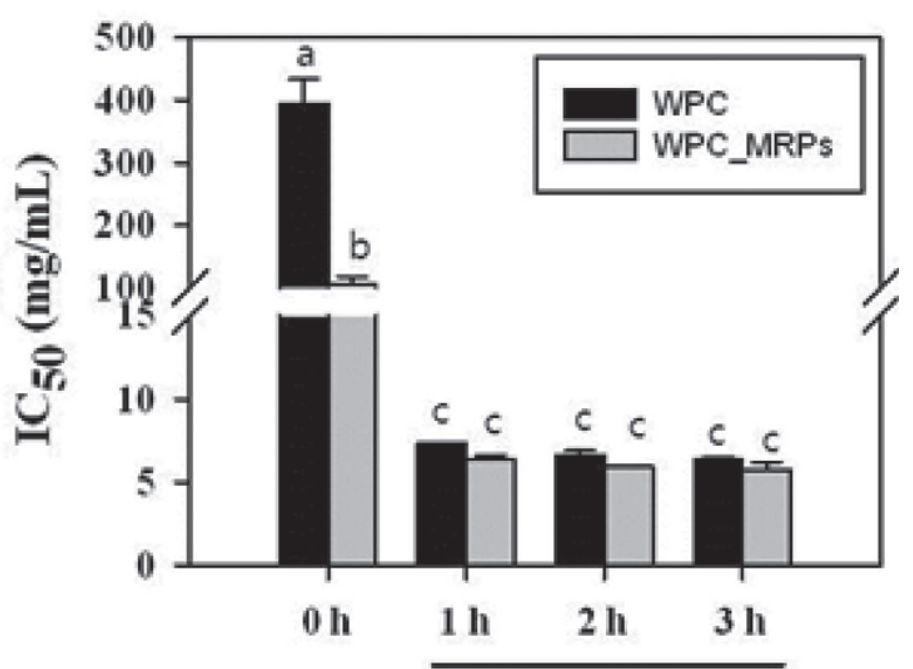

Neutrase

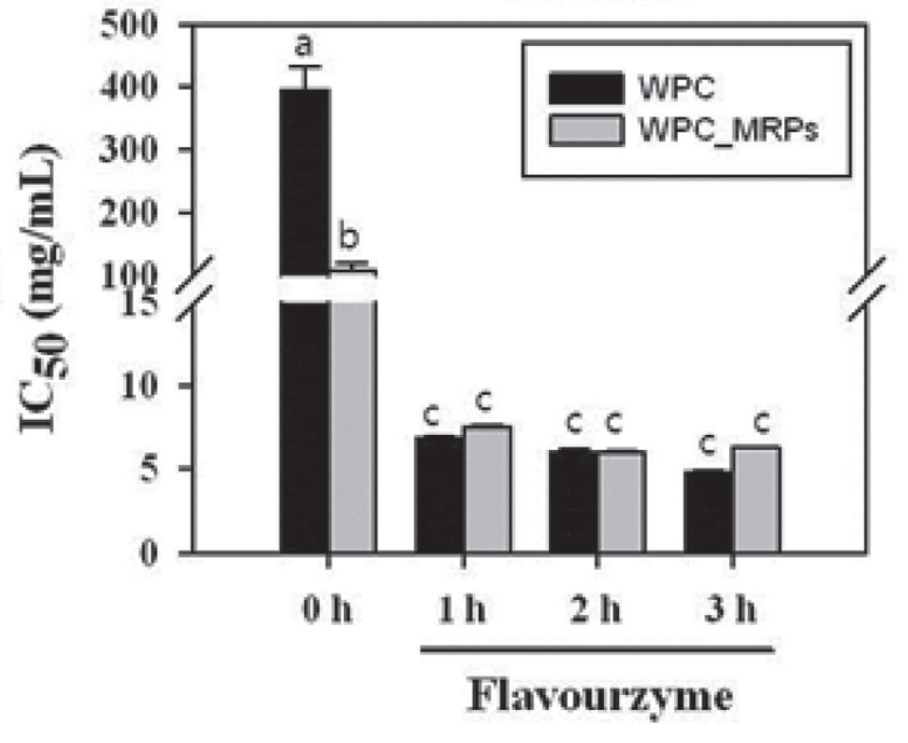

Figure 6. The 2,2'-azino-bis(3-ethylbenzothiazoline-6-sulfonic acid) diammonium salt (ABTS) radical-scavenging activity of whey protein concentrates (WPC) hydrolysates and Maillard-reacted WPC. All enzymes were from Novozymes (Bagsværd, Denmark). Values are expressed as the mean $\pm \mathrm{SD}(\mathrm{n}=3)$. Data followed by a different lowercase letter $(\mathrm{a}-\mathrm{c})$ were significantly different $(P<0.05)$. MRP $=\mathrm{Maillard}$ reaction products; $\mathrm{IC}_{50}=$ concentration of sample required to scavenge $50 \%$ of the ABTS radical.

hydrolysis by Neutrase resulted in the appearance of bands of protein with small molecular weight that were absent from the nontreated SC. In addition, the bands with higher molecular weight were also formed from SC after the Maillard reaction, and these were then completely hydrolyzed by Alcalase and partly hydrolyzed by the other enzymes. These different patterns of bands indicated that the hydrolytic enzymes had different catalytic sites and different modes of action, regardless of the $\mathrm{DH}(\%)$. In previous studies, $\alpha-\mathrm{LA}$ and $\beta-\mathrm{LG}$ were completely hydrolyzed by Alcalase and only partly hydrolyzed by Flavorzyme (Lin et al., 2012), in agreement with our results.

\section{Determination of Antioxidant Activity}

The antioxidant activity of natural compounds is dependent on the experimental procedures due on their different reaction mechanisms. Therefore, we employed a DPPH assay for determining free radical scavenging activity, an ABTS assay for cations radical scavenging activity, and a FRAP assay for reducing ability. Initially, the free radical scavenging activity was evaluated by reacting milk protein and MRP hydrolysates with a stable DPPH free radical. Antioxidant activity was expressed as free radical scavenging activity (\%). The changes in the DPPH free radical scavenging activity 

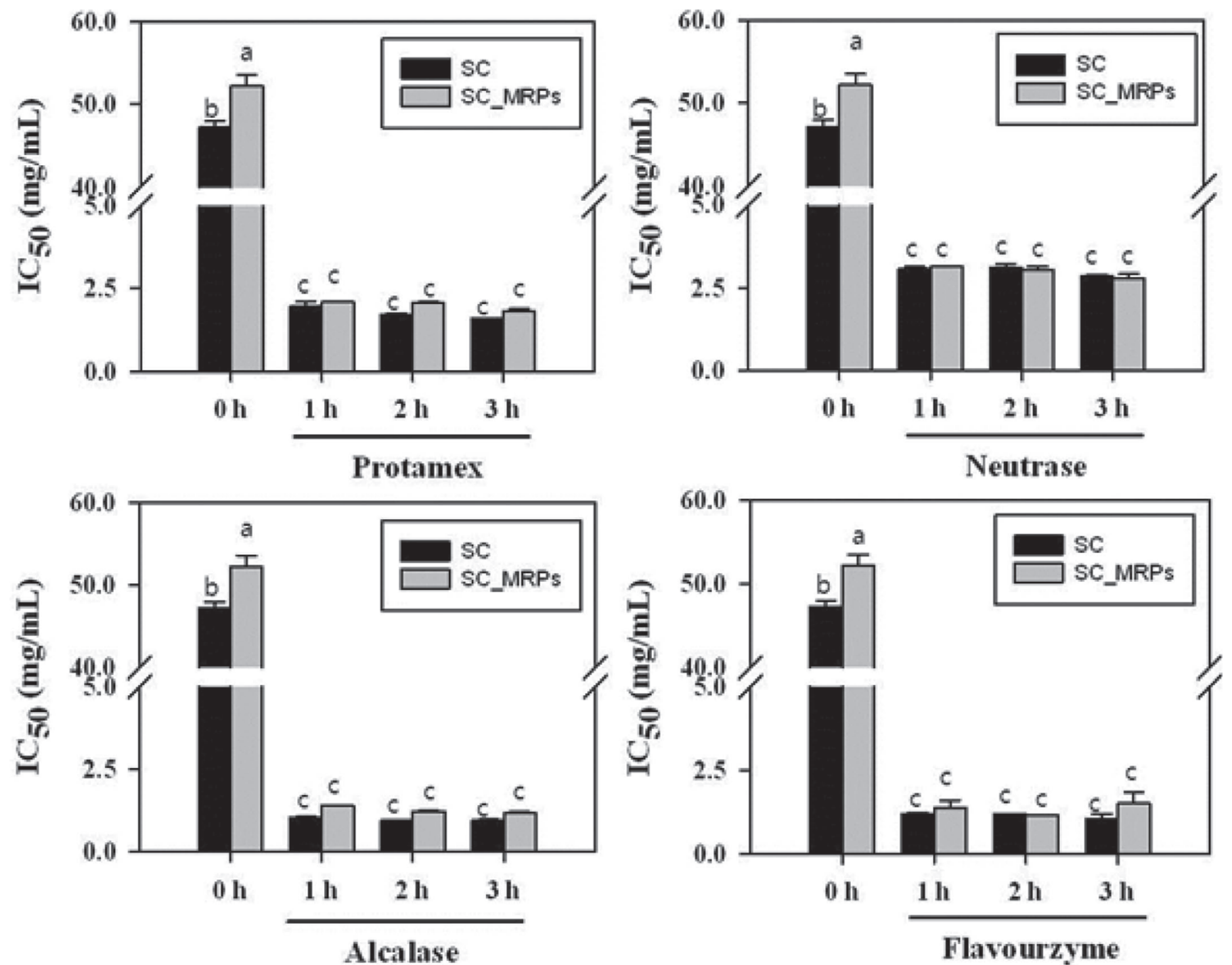

Figure 7. The 2,2'-azino-bis(3-ethylbenzothiazoline-6-sulfonic acid) diammonium salt (ABTS) radical-scavenging activity of sodium caseinate (SC) hydrolysates and Maillard-reacted SC. All enzymes were from Novozymes (Bagsværd, Denmark). Values are expressed as the mean \pm $\mathrm{SD}(\mathrm{n}=3)$. Data followed by a different lowercase letter $(\mathrm{a}-\mathrm{c})$ were significantly different $(P<0.05)$. MRP $=\mathrm{Maillard}$ reaction products; $\mathrm{IC}_{50}$ $=$ concentration of sample required to scavenge $50 \%$ of the ABTS radical.

of Maillard-reacted WPC and SC with hydrolysis time are shown in Figures 4 and 5. Scavenging activity was gradually increased with increasing hydrolysis time, especially after $1 \mathrm{hr}$. The activity of MRP hydrolysates was dramatically higher than for intact hydrolysates. In particular, MRP from both WPC and SC treated for $3 \mathrm{~h}$ with Alcalase showed the highest scavenging activity among different enzymes at $30.3 \pm 0.8$ and $26.8 \pm 0.6 \%$, respectively. Compared to ascorbic acid $(100 \mu \mathrm{g} / \mathrm{mL})$ as a positive control, MRP treated with Alcalase showed $82.61 \%$ scavenging activity (data not shown). A previous study showed that intermediate or final compounds from the Maillard reaction could func- tion as hydrogen donors, which contributed to increase radical scavenging activity (Benjakul et al., 2005).

In addition, the ABTS assay provided a measurement of the antioxidant activity of hydrolyzed MRP by measuring the reduction of the radical cation (Sun et al., 2006). The changes in the ABTS free radical scavenging activity of MRP from WPC and SC are shown in Figures 6 and 7 . The $\mathrm{IC}_{50}$ values of MRP were significantly lower for WPC and SC $(106 \pm 11$ and 52 $\pm 1 \mathrm{mg} / \mathrm{mL}$, respectively) than for intact WPC and $\mathrm{SC}(395 \pm 38$ and $47.2 \pm 0.8 \mathrm{mg} / \mathrm{mL}$, respectively). After hydrolysis by Alcalase, the $\mathrm{IC}_{50}$ values were dramatically decreased, to $2.1 \pm 0.3$ and $1.17 \pm 0.03 \mathrm{mg} /$ 

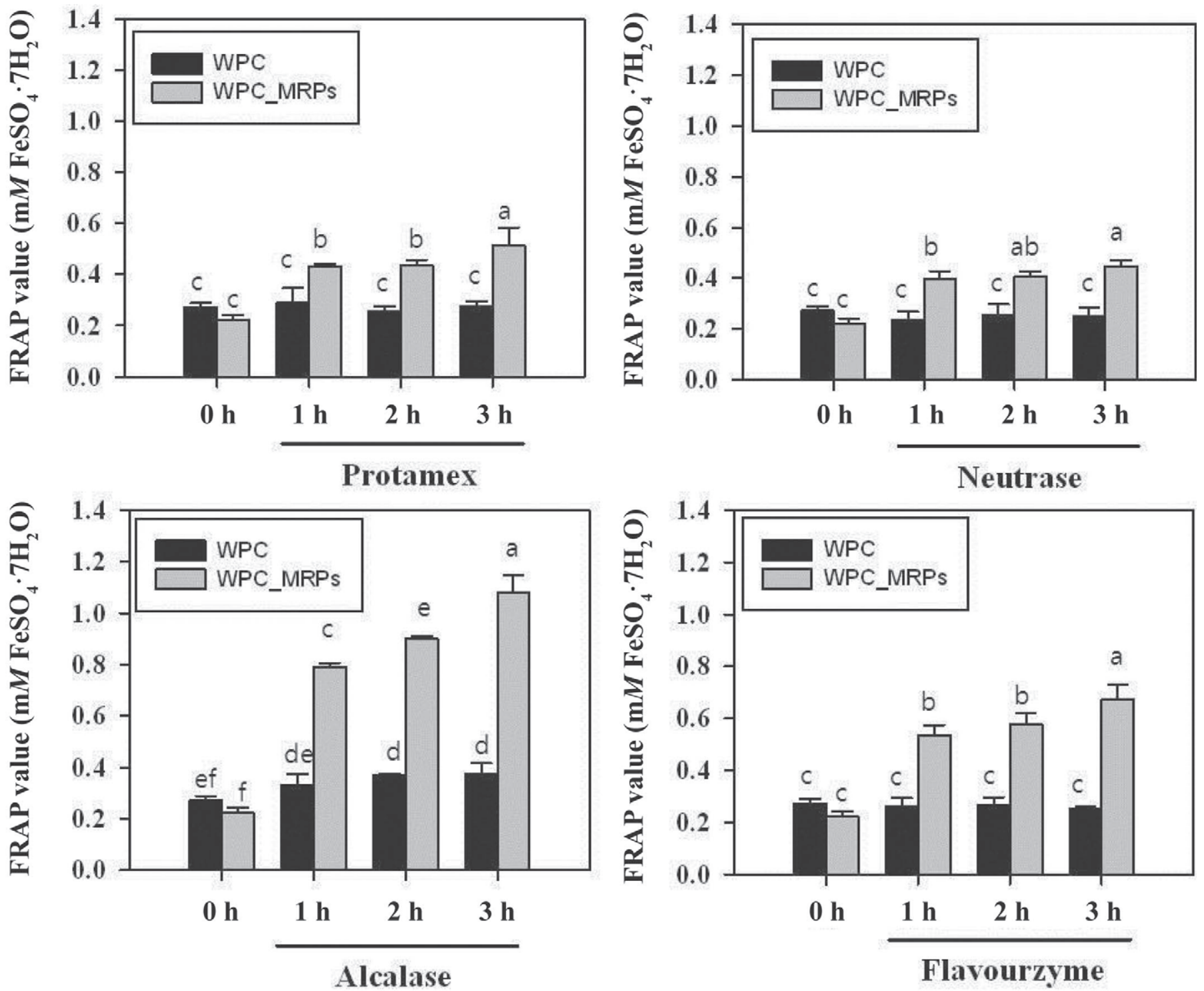

Figure 8. Ferric-reducing antioxidant power (FRAP) of whey protein concentrates (WPC) hydrolysates and Maillard-reacted WPC hydrolysates. Values are expressed as the mean $\pm \mathrm{SD}(\mathrm{n}=3)$. Data followed by a different lowercase letter $(\mathrm{a}-\mathrm{f})$ were significantly different $(P<$ 0.05). MRP $=$ Maillard reaction products.

$\mathrm{mL}$, respectively. Conversely, the $\mathrm{IC}_{50}$ value of ascorbic acid was $52.18 \pm 0.03 \mu \mathrm{g} / \mathrm{mL}$ (data not shown), which indicated that the Maillard reaction could contribute to increased radical scavenging activity, though not to as great an extent as ascorbic acid. After $1 \mathrm{~h}$ of hydrolysis with different enzymes, the ABTS radical scavenging activity was dramatically improved, whereas no significant difference was noted for hydrolysates produced by 1-, 2-, and 3-h enzyme treatments. The MRP produced from both WPC and SC after a $3 \mathrm{~h}$ Alcalase treatment showed the highest ABTS scavenging activity when compared with the other enzymes.
Finally, additional FRAP assays were performed to investigate reducing power, which was indicated by the absorbance of the intense blue ferrous tripyridyltriazine complex at $562 \mathrm{~nm}$. The changes in the FRAP value of MRP from WPC and SC are shown in Figures 8 and 9. Ascorbic acid $(100 \mu \mathrm{g} / \mathrm{mL})$, as a positive control, gave a value of $2.04 \pm 0.01 \mathrm{mM} \mathrm{FeSO} \cdot 7 \mathrm{H}_{2} \mathrm{O}$ equivalents (data not shown). The WPC hydrolysates and SC hydrolysates treated with the 4 enzymes had widely different amounts of antioxidant power, ranging from 0.16 \pm 0.02 to $1.08 \pm 0.07 \mathrm{mM} \mathrm{FeSO} \cdot \cdot 7 \mathrm{H}_{2} \mathrm{O}$ equivalents. Corroborating our previous results, the highest reduc- 

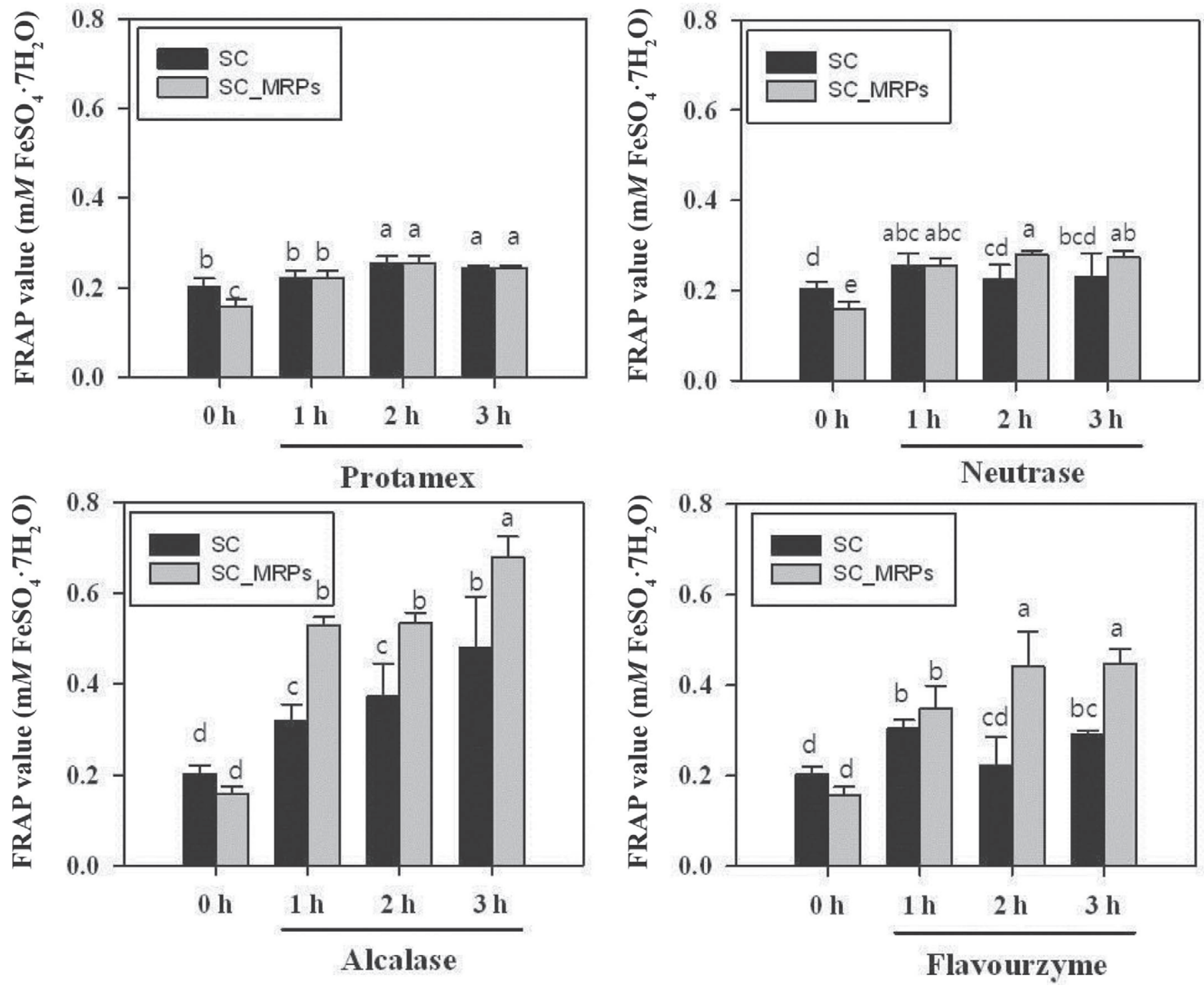

Figure 9. Ferric-reducing antioxidant power (FRAP) of sodium caseinate (SC) hydrolysates and Maillard-reacted SC hydrolysates. Values are expressed as the mean $\pm \mathrm{SD}(\mathrm{n}=3)$. Data followed by a different lowercase letter $(\mathrm{a}-\mathrm{e})$ were significantly different $(P<0.05)$. MRP $=$ Maillard reaction products.

ing power was observed for the WPC and SC hydrolysates treated for $3 \mathrm{~h}$ with Alcalase, at $1.08 \pm 0.07$ and $0.68 \pm 0.05 \mathrm{mM} \mathrm{FeSO} \cdot \cdot 7 \mathrm{H}_{2} \mathrm{O}$ equivalents, respectively. The values for the nontreated $\mathrm{WPC}$ and $\mathrm{SC}$ were 0.37 \pm 0.04 and $0.48 \pm 0.11 \mathrm{mM} \mathrm{FeSO}{ }_{4} \cdot 7 \mathrm{H}_{2} \mathrm{O}$ equivalents, respectively, which indicated that the Maillard reaction could have a positive effect on the reducing power of milk protein hydrolysates. Although the FRAP values of intact WPC and SC were not increased by hydrolysis time, those of MRP from both WPC and SC were significantly increased by time. The radical scavenging activity was strongly correlated with reducing power. The antioxidant activity results indicated a contribu- tion of the Maillard reaction to enhancement of the antioxidant activity.

Similar studies have been conducted on the antioxidant activity of MRP. For example, McGookin and Augustin (1991) found that reaction of MRP with casein and glucose or lactose improved antioxidant activity. Others also reported that MRP could serve as electron donors ( $\mathrm{Gu}$ et al., 2009) and that antioxidant activity of porcine plasma protein hydrolysates in relation to DH, and increasing DH (\%) significantly increased the DPPH radical scavenging activity and reducing power. Similar results were also observed in a previous study by Dryáková et al. (2010), who evaluated the 
development of the antioxidant activity in relation to hydrolysis time. The ABTS radical scavenging results indicated that Alcalase hydrolysates had the highest radical scavenging activity and Neutrase or Protamex hydrolysates had the lowest radical scavenging activity. The probable reason for this reaction was that hydrolysis could disrupt the protein structure and, consequently, produce and alter its functional properties (Kristinsson and Rasco, 2000). However, the ABTS scavenging activity of hydrolyzed MRP was slightly different from that obtained by the FRAP assay. This difference in antioxidant activity could be due to the different reaction mechanisms. The FRAP assay detects compounds that act only by a single electron transfer mechanism, whereas the ABTS assay detects compounds that act either by direct reduction via electron transfer or by radical quenching via the hydrogen atom transfer mechanism (Prior et al., 2005). These data indicate that the hydrolyzed-MRP generated by Alcalase showed significantly higher antioxidant activity when compared with the other protease products and the antioxidant activity was higher for the WPC groups than for the SC groups.

\section{CONCLUSIONS}

In this study we evaluated the characteristics and antioxidant activity of hydrolyzed MRP derived from WPC and SC. The furosine content of the MRP decreased in WPC and increased in SC. The fluorescence intensity of MRP increased gradually with the duration of heating and the $\mathrm{DH}$ values increased with hydrolysis time, with the highest values seen for Flavorzyme-treated hydrolysates. Antioxidant properties, determined by DPPH, ABTS, and FRAP assays, were enhanced by the Maillard reaction and hydrolysis of WPC and $\mathrm{SC}$. The greatest antioxidant properties among the 4 commercial enzymes were obtained for Alcalase-treated MRP. These results revealed that functional proteins or peptides with antioxidant activity could be produced by the Maillard reaction and hydrolysis. Accordingly, Maillard-reacted milk protein hydrolysates could be used as potential antioxidants in the pharmaceutical and dairy industries. The Maillard-reacted milk protein hydrolysates might have other effects based on their antioxidant activity, such as anti-inflammatory and therapeutic effects on cardiovascular diseases. Further studies are needed to investigate additional functional properties.

\section{ACKNOWLEDGMENTS}

This research was supported by the High Value-Added Food Technology Development Program of the Korea
Institute of Planning and Evaluation for Technology in Food, Agriculture, Forestry, and Fisheries, and the Ministry for Food, Agriculture, Forestry, and Fisheries of Republic of Korea (111137-03-2-SB010).

\section{REFERENCES}

Angel Rufian-Henares, J., E. Guerra-Hernández, and B. García-Villanova. 2002. Maillard reaction in enteral formula processing: Furosine, loss of $o$-phthaldialdehyde reactivity, and fluorescence. Food Res. Int. 35:527-533.

Benjakul, S., W. Visessanguan, and M. Tanaka. 2005. Properties of phenoloxidase isolated from the cephalothorax of kuruma prawn (Penaeus japonicus). J. Food Biochem. 29:470-485.

Benzie, I. F., and J. J. Strain. 1996. The ferric reducing ability of plasma (FRAP) as a measure of "antioxidant power": The FRAP assay. Anal. Biochem. 239:70-76.

Bertrand-Harb, C., A. Baday, M. Dalgalarrondo, J. M. Chobert, and T. Haertle. 2002. Thermal modifications of structure and co-denaturation of $\alpha$-lactalbumin and $\beta$-lactoglobulin induce changes of solubility and susceptibility to proteases. Nahrung 46:283-289.

Blois, M. S. 1958. Antioxidant determinations by the use of a stable free radical. Nature 181:1199-1200.

Chevalier, F., J. M. Chobert, C. Genot, and T. Haertle. 2001. Scavenging of free radicals, antimicrobial, and cytotoxic activities of the Maillard reaction products of beta-lactoglobulin glycated with several sugars. J. Agric. Food Chem. 49:5031-5038.

Dryáková, A., A. Pihlanto, P. Marnila, L. Čurda, and H. J. T. Korhonen. 2010. Antioxidant properties of whey protein hydrolysates as measured by three methods. Eur. Food Res. Technol. 230:865874.

Fayle, S. E., and J. Gerrard. 2002. The Maillard Reaction. Vol. 5. Royal Society of Chemistry, Cambridge, UK.

FitzGerald, R. J., and H. Meisel. 2000. Milk protein-derived peptide inhibitors of angiotensin-I-converting enzyme. Br. J. Nutr. 84:3337.

Fox, P. F., and P. L. H. McSweeney. 2003. Advanced Dairy Chemistry. Vol. 1. Plenum Publishing Corp., New York, NY.

Gauthier, S. F., Y. Pouliot, and D. Saint-Sauveur. 2006. Immunomodulatory peptides obtained by the enzymatic hydrolysis of whey proteins. Int. Dairy J. 16:1315-1323.

Gu, F., J. M. Kim, K. Hayat, S. Xia, B. Feng, and X. Zhang. 2009. Characteristics and antioxidant activity of ultrafiltrated Maillard reaction products from a casein-glucose model system. Food Chem. 117:48-54.

Guerra-Hernández, E., N. Corzo, and B. Garcia-Villanova. 1999. Maillard reaction evaluation by furosine determination during infant cereal processing. J. Cereal Sci. 29:171-176.

Haque, E., and R. Chand. 2008. Antihypertensive and antimicrobial bioactive peptides from milk proteins. Eur. Food Res. Technol. 227:7-15.

Hollnagel, A., and L. Kroh. 1998. Formation of $\alpha$-dicarbonyl fragments from mono-and disaccharides under caramelization and Maillard reaction conditions. Z. Lebensm. Unters. Forsch. A 207:50-54.

Jing, H., and D. Kitts. 2002. Chemical and biochemical properties of casein-sugar Maillard reaction products. Food Chem. Toxicol. 40:1007-1015.

Kristinsson, H. G., and B. A. Rasco. 2000. Biochemical and functional properties of Atlantic salmon (Salmo salar) muscle proteins hydrolyzed with various alkaline proteases. J. Agric. Food Chem. 48:657-666.

Laemmli, U. K. 1970. Cleavage of structural proteins during the assembly of the head of bacteriophage T4. Nature 227:680-685.

Lin, S., W. Tian, H. Li, J. Cao, and W. Jiang. 2012. Improving antioxidant activities of whey protein hydrolysates obtained by thermal preheat treatment of pepsin, trypsin, alcalase and flavourzyme. Int. J. Food Sci. Technol. 47:2045-2051.

McGookin, B. J., and M.-A. Augustin. 1991. Antioxidant activity of casein and Maillard reaction products from casein-sugar mixtures. J. Dairy Res. 58:313-320. 
Nielsen, P., D. Petersen, and C. Dambmann. 2006. Improved method for determining food protein degree of hydrolysis. J. Food Sci. 66:642-646.

Nursten, H. E. 2005. The Maillard Reaction: Chemistry, Biochemistry and Implications. Royal Society of Chemistry, Cambridge, UK.

Pihlanto, A. 2006. Antioxidative peptides derived from milk proteins. Int. Dairy J. 16:1306-1314.

Prior, R. L., X. Wu, and K. Schaich. 2005. Standardized methods for the determination of antioxidant capacity and phenolics in foods and dietary supplements. J. Agric. Food Chem. 53:4290-4302.

Re, R., N. Pellegrini, A. Proteggente, A. Pannala, M. Yang, and C. Rice-Evans. 1999. Antioxidant activity applying an improved ABTS radical cation decolorization assay. Free Radic. Biol. Med. 26:1231-1237.
Reed, G. 1975. Enzymes in Food Processing. 2nd ed. Academic Press Inc., New York, NY.

Shah, N. P. 2000. Effects of milk-derived bioactives: An overview. Br. J. Nutr. 84(Suppl. 1):S3-S10.

Sun, Y., S. Hayakawa, S. Puangmanee, and K. Izumori. 2006. Chemical properties and antioxidative activity of glycated $\alpha$-lactalbumin with a rare sugar, D-allose, by Maillard reaction. Food Chem. 95:509-517.

Yeboah, F. K., I. Alli, and V. A. Yaylayan. 1999. Reactivities of Dglucose and D-fructose during glycation of bovine serum albumin. J. Agric. Food Chem. 47:3164-3172. 